\title{
SPA SERVICES DISTRIBUTION AND SPA SPECIALIZATION IN EASTERN POLAND SPA COMMUNES
}

\author{
PAWEE STELMACH
}

University of Physical Education in Kraków, POLAND

e-mail: pawel.stelmach@awf.krakow.pl

\author{
RECEIVED \\ ACCEPTED \\ 1 September 2017 \\ JEL \\ CLASSIFICATION \\ C12, H71, L83, Z30
}

KEYWORDS

spa specialization, tourism specialization, spa, distribution, spa resort

ABSTRACT

The aim of the paper is to identify and explain the relation between spa services distribution and spa specialization of Lubelskie (Nałęczów), Podlaskie (Augustów), Świętokrzyskie (Busko-Zdrój and SolecZdrój) and Warmińsko-Mazurskie (Gołdap) spa communes. Time series analysis techniques, Spearman rank correlation analysis and linear regression analysis were used. Spa services distribution was measured by the share of non-commercial spa inpatient number in total spa inpatient number, whereas spa specialization was measured by the share of nights spent in spa establishments in total nights spent. Statistical data came from the Central Statistical Office of Poland Local Data Bank and the unpublished data collection obtained from the Statistical Office in Kraków. In the case of Nałęczów analysed relationship is functional, where a rise in number of nights spent in connection with the growth of spa specialization and the increase in spa service distribution - a risky combination of trends, due to increasing dependence on the state distribution channel.

\section{Introduction}

The chosen research problem is the verification of the relationship between the spa services distribution (SSD) and spa specialization of the Lubelskie, Podlaskie, Świętokrzyskie and Warmińsko-Mazurskie communes. The aim is to identify and explain this relation. The following question was asked: if, and if so - to what extent, analysed relation is a correlation or functional relationship? The research hypothesis is placed: the strength of the relation 
in question is varied, with two groups of communes separated: partly with stronger and statistically significant correlation and functional relationships and partly with weaker and statistically insignificant. The research subject are the spa communes, i.e. which possess in their territory areas with the status of a health resort.

The spa communes of the Lubeskie (Nałęczów), Podlaskie (Augustów), Świętokrzyskie (Busko-Zdrój, SolecZdrój) and Warmińsko-Mazurskie (Gołdap) voivodeships concentrated in the years 1995-2014 7\% of the tourist traffic in the spa communes in Poland (excluding Kraków), measured by the nights spent number (Central Statistical Office of Poland Local Data Bank - CSOP LDB).

Among the mentioned spa communes particular important is Busko, which is the 9th place in Poland among the spa destinations (excluding Kraków) according to nights spent (0.5 million) in 2014, and also in 6th place in Poland in terms of nights spent in spa establishments (0.4 million) (CSOP LDB).

In spa towns, as tourism destinations, spa services are distributed through two complementary channels: market (commercial) and state (social). They were described in another study (Stelmach, 2017c).

In the light of wider characteristics of spa and tourism specialization (Stelmach, 2017c) and the operationalization of the spa specialization (Stelmach, 2017a), the spa specialization is understood as a part of the spa economy within the tourism economy, whereas tourism specialization is a part of tourism economy in the economy.

The rest of the paper is organized as follows: a literature review introduces the current status of reseach, a method and data sources section provides the particular research aims, research techniques and data origins used for analyzing the research issue; the results section presents research findings; while the last section concludes the paper and suggests further directions and policy implications.

\section{Literature review}

The presented study is the next in a series of already published author's works on the relationship between spa service distribution and spa specialization. So far (Stelmach, 2017acde), the relationship between SSD and spa specialization has been analyzed for 17 spa communes in Podkarpackie, Kujawsko-Pomorskie, Pomorskie, Małopolskie and Śląskie voivodeships, which combined in 1995-2014 48\% tourist traffic measured in terms of number of nights spent (CSOP LDB). Other studies didn't compare the phenomena of SSD and spa specialization, usually analyzing these issues separately.

Research on the SSD has focused on the duality and diversification of distribution channels and its consequences for spa companies and communes (Romanova et al., 2015; Derco, Pavlisinova, 2016; Dryglas, Różycki, 2016, 2017; Dryglas, Salamaga, 2017; Kozarkiewicz, Kabalska, 2017; Stelmach, 2017ab; Szromek et al., 2016; Vrkljan, Hendija, 2016). Existing research in these two areas has produced the following conclusions (Stelmach, 2017a):

1. The current excessive dependence of spas in some countries on the spa services state distribution channel is risky, as sudden legal or financial regulatory shocks can pose an economic threat to spa companies and communes. Moreover, non-commercial spa patients bring less income to both spa companies and communes.

2. Commercial spa patients are key customers because they provide greater value for spa companies and destinations in the form of higher spending and more valuable feedback. For some spa communes, foreign spa patients are the key guests. The ability to attract a commercial spa patient is a strategic challenge for spa communes. 
It has been established (Stelmach, 2017a) that a total of 34 Polish spa communes treated jointly, ${ }^{1}$ representing $79 \%$ of spa communes in Poland, ${ }^{2}$ have a strong (Spearman correlation coefficient of -0.9 ), a statistically significant negative correlation. This result can be interpreted as a strong positive relationship between SSD and non-spa specialization or between state SSD and spa specialization.

In addition, it has been identified (Stelmach, 2017e) that the strength of the relation in question is varied, with two groups of communes separated: mostly with stronger and statistically significant relationships and rarely with weaker and statistically insignificant. Within the group of communes for which the relationships are statistically significant, SSD is usually negatively correlated to spa specialization.

Four different development patterns of spa communes were identified and evaluated, among which mostly the rise of nights spent is connected with the growth of spa specialization and the decrease of SSD, which is a risky combination of trends due to growing dependence on state distribution channel. Identified different development patterns may have an impact on the balance of benefits and costs of service for spa patients and tourists by spa companies and destinations.

\section{Method}

Table 1 shows the research procedure and the ordered set of research techniques and sources comprising the method.

Tahela 1. Research method

\begin{tabular}{|c|c|c|}
\hline Purpose of research & Data sources & Research techniques \\
\hline $\begin{array}{l}\text { Identification of time series } \\
\text { for SSD }\end{array}$ & $\begin{array}{l}\text { Secondary data concerning } 5 \text { Polish spa communes from } 2005 \\
\text { to } 2015 \text {, originating from an unpublished data set from CSOP } \\
\text { from the Statistical Office in Kraków }\end{array}$ & \multirow[t]{2}{*}{ Time series analysis } \\
\hline $\begin{array}{l}\text { Identification of a time series } \\
\text { for spa specialization }\end{array}$ & $\begin{array}{l}\text { Secondary data concerning } 5 \text { Polish spa communes from 2005-2014 } \\
\text { from the CSOP }\end{array}$ & \\
\hline $\begin{array}{l}\text { Estimation of the correlation } \\
\text { and dependence between SSD } \\
\text { and spa specialization }\end{array}$ & $\begin{array}{l}\text { Secondary data concerning } 5 \text { spa communes from 2005-2014 } \\
\text { from the CSOP unpublished data and LDB }\end{array}$ & $\begin{array}{l}\text { 1. Analysis of Spearman rank correlation. } \\
\text { 2. Student's t test for statistical } \\
\text { significance of correlation coefficients. } \\
\text { 3. Regression analysis }\end{array}$ \\
\hline
\end{tabular}

Source: author.

Quantitative techniques were used to accomplish the goal and answer question. Time series analysis serves to improve understanding of the variability of correlations and to identify their properties such as trends and periodicity. Spearman correlation analysis with a student t-test is used to identify statistically significant relationships between variables with asymmetric distribution and the small number of available observations. Simple regression analysis models the relationships between dependent variable (spa specialization) and independent variable (SSD).

The spatial extent of the research included two spa communes of Świętokrzyskie voivodeship (Busko, Solec) and one of the Lubelskie (Nałęczów), Podlaskie (Augustów) and Warmińsko-Mazurskie (Gołdap), identified as

\footnotetext{
${ }^{1}$ These spa communes are listed in another study (Stelmach, 2017c).

${ }^{2}$ For 9 communes the data deficiencies have not allowed for the estimation of correlation coefficients. They are enumerated in another study (Stelmach, 2017c).
} 
having available data for correlation and regression analysis for 2005-2014. The use of secondary data was justified in another study (Stelmach, 2017c).

The relatively small number of observations $(N=10,2005-2014)$ was because of the length of time the CSOP has collected statistics on the commercial spa inpatients (data available from 2005) and the coming into force of an amendment to the Public Statistics Act of 2015, which resulted in the CSOP ceasing access to data on the nights spent at commune level from 2015.

In order to measure the theoretical constructs used in the study, the concepts of the SSD and the spa specialization were operationalized. Differently from Stelmach's (2017a) work, the SSD of was measured by:

SSD indicator = non-commercial spa inpatent number/total spa inpatient number,

where inpatient means patient using treatment on a 24-hour or on a daytime basis, i.e. in a sanatorium or spa resort hospital.

For reasons given in P. Stelmach (2017a) spa specialization was measured using:

Spa specialization indicator $=$ nights spent in spa establishments/total nights spent in tourist accomodation establishments, where a spa establishment is a health care provider located in the spa commune and uses natural healing resources in the provision of health services.

In addition, taking into account the conclusions of the previous works (Stelmach, 2017de), the time-series analysis of nights spent was also used to identify the development patterns of spa communes.

\section{Results}

The identified time series for SSD are presented on Figure 1.

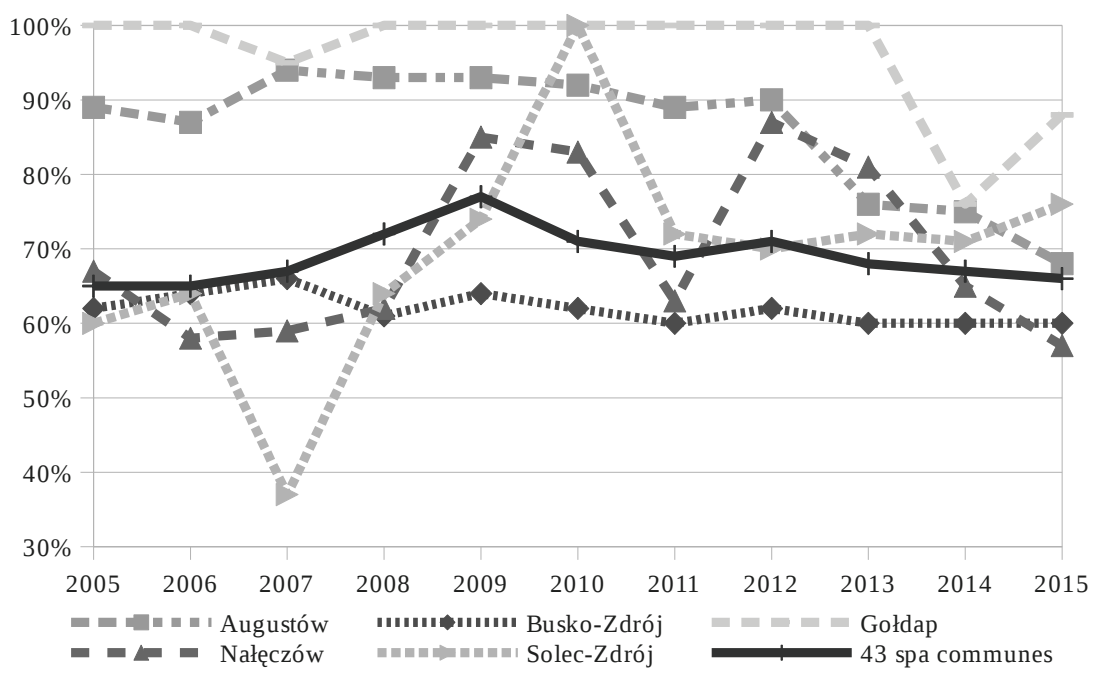

Figure 1. SSD in Eastern Poland spa communes: 2005-2015

Source: author, based on unpublished data from CSOP acquired from the Statistical Office in Kraków. 
In Figure 1, there is a common pattern of growth in SSD can be seen. It is countercyclical (Mankiw, Taylor, 2016), i.e. inconsistent with economic cycles, which is evident especially in relation to the series of data referring to the 43 spa communes. A similar variation of the indicator, above national average can be noted for Busko, while the greater fluctuations can be seen in Nałeczów and Solec. In Augustów, Gołdap and Busko SSD is falling, whereas in Nałęczów and Solec is rising.

In turn, the identified time series for spa specialization is shown on Figure 2.

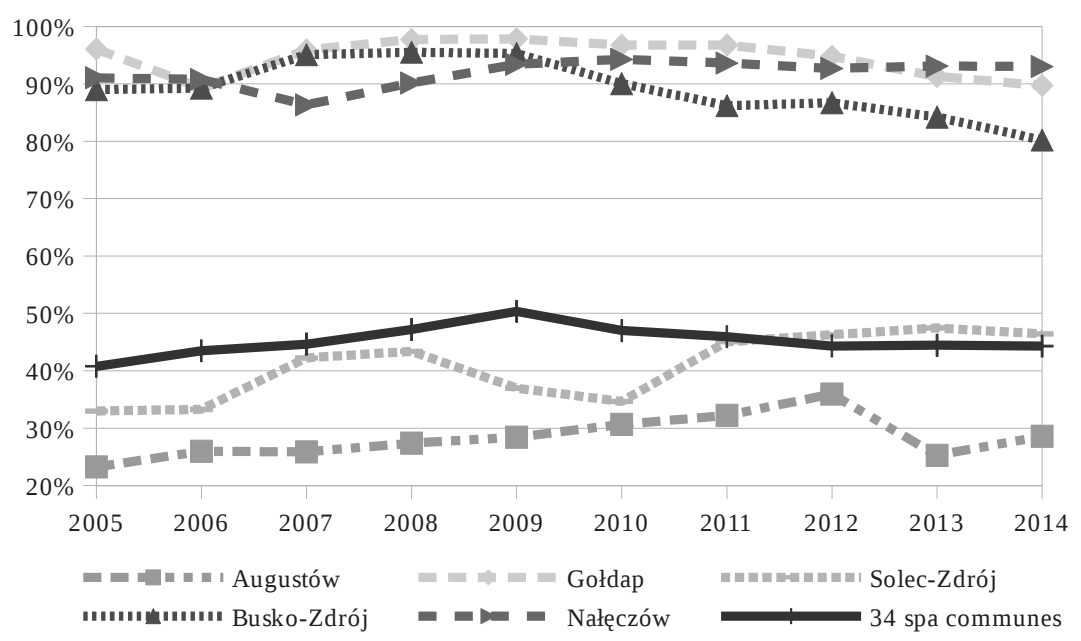

Note: Due to doubts about the value of Busko and Solec data in 2005, data interpolation was used by adopting for this year the same indicator value as in 2006.

Figure 2. Changes in spa specialization in in Eastern Poland spa communes: 2005-2014

Source: author, based on CSOP LDB.

In Figure 2, two groups of spa communes having different level of spa specialization are noticeable. In Nałęczów, Gołdap and Busko spa specialization is much above average for 34 Polish spa communes, ${ }^{3}$ dominating in tourism specialization. In Solec and Augustów spa specialization is much lower, closer to national average. In Nałęczów, Solec and Augustów spa specialization is rising, whereas in Gołdap and Busko falling. Spa specialization indicator variability for 34 communes is countercyclical (Mankiw, Taylor, 2016), i.e. negatively correlates with periods of economic growth.

Considering importance of number of nights spent as a key variable correlated with destination revenues from visitors spendings, in Figure 3 time-series of that variable is shown.

\footnotetext{
${ }^{3}$ For nine communes data for counting that indicator was not avaiable.
} 


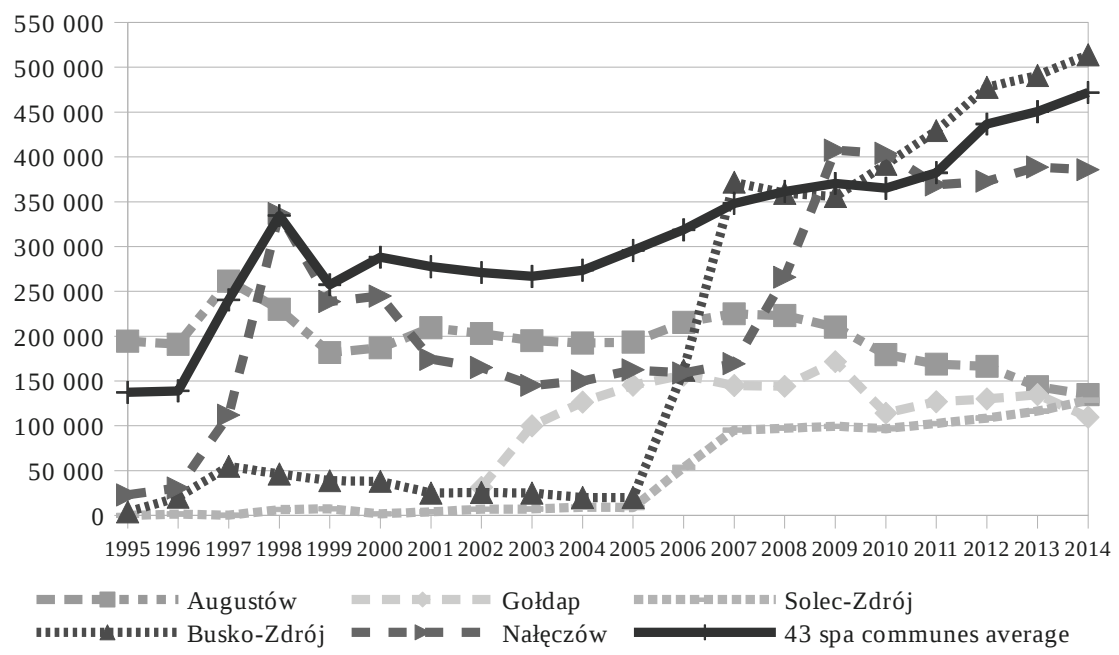

Figure 3. Number of nights spent in in Eastern Poland spa communes: 1995-2014

Source: author, based on CSOP LDB.

For 43 communes, Busko, Nałęczów, Gołdap and Solec number of nights spent is rising, whereas for Augustów falling. From 2009 to 2014 number of nights spent in Busko and Nałęczów was close to national average, i.e. approximately between 400 and 500 thousand, whereas in Augustów, Solec and Gołdap between 100 and 200 thousand.

Table 2 shows outcomes for the correlation analysis.

Tahbla 2. Spearman's correlation coefficients between SSD and spa specialization: 2005-2014

\begin{tabular}{cccccc}
\hline Augustów & Busko & Gołdap & Nałęczów & Solec & $\begin{array}{c}\text { The critical value of the correlation coefficient for } \mathrm{N}=10 \text { and } p=0.05 \\
\text { (two-sided critical area) }\end{array}$ \\
\hline 0.11 & 0.53 & 0.17 & $\mathbf{0 . 6}$ & 0.2 & 0.65 \\
\hline
\end{tabular}

Source: author, based on CSOP LDB and unpublished data from the Statistical Office in Kraków.

For Nałęczów and Busko were estimated high and (in case of Nałęczów) close to statistical significancy positive relation between SSD and spa specialization, whereas for Augustów, Gołdap and Solec correlations were weak, positive and insignificant.

Outcomes of regression analysis are shown in Table 3.

Verification of the statistical significance of the explanatory variable, with the level $a=0.05$, was based on the hypotheses:

$\mathrm{H}_{0}$ : independent variable significantly influences the dependent variable,

$\mathrm{H}_{1}$ : independent variable does not significantly affect the dependent variable. 
Tahela 3. Ordinary least squares estimation for spa specialization dependent variable and SSD independent variable

\begin{tabular}{|c|c|c|c|c|c|}
\hline Commune & & & $p$ value & $\mathrm{R}^{2}$ & $\begin{array}{l}\text { Akaike information } \\
\text { criterion }\end{array}$ \\
\hline \multirow{2}{*}{ Nałęczów } & intercept & 0.96 & $<0.0001$ & \multirow{2}{*}{0.41} & \multirow{2}{*}{-49} \\
\hline & SSD & 0.13 & 0.047 & & \\
\hline \multirow{2}{*}{ Gołdap } & intercept & -0.01 & 0.82 & \multirow{2}{*}{0.05} & \multirow{2}{*}{-8} \\
\hline & SSD & -0.12 & 0.52 & & \\
\hline \multirow{2}{*}{ Busko } & intercept & 0.39 & $<0.0001$ & \multirow{2}{*}{0.04} & \multirow{2}{*}{6} \\
\hline & SSD & 0.01 & 0.6 & & \\
\hline \multirow{2}{*}{ Augustów } & intercept & 0.29 & $<0.0001$ & \multirow{2}{*}{0.03} & \multirow{2}{*}{-35} \\
\hline & SSD & 0.09 & 0.65 & & \\
\hline \multirow{2}{*}{ Solec } & intercept & 0.4 & 0.007 & \multirow{2}{*}{0.01} & \multirow{2}{*}{-8} \\
\hline & SSD & 0.07 & 0.83 & & \\
\hline
\end{tabular}

Source: author.

As Table 3 shows, the statistically significant and moderately matched dependence of spa specialization on SSD for Nałęczów were obtained. In other cases dependencies proved to be unmatched and statistically insignificant.

\section{Conclusions}

The research made it possible to answer the research question posed. The above-mentioned research results confirm the regularities identified in previous study (Stelmach, 2017d), thanks to analysing 22 Polish spa communes from Kujawsko-Pomorskie, Pomorskie, Podkarpackie, Małopolskie, Śląskie, Lubelskie, Podlaskie, Świętokrzyskie and Warmińsko-Mazurskie voivodeships:

1. The strenght of relation in question is varied, with two groups of communes separated: ten communes with stronger and statistically significant relationships (Horyniec, Ciechocinek, Inowrocław, Solina, Ustka, Uście Gorlickie, Kraków, Ustroń, Goczałkowice, Nałęczów) and twelve with weaker and statistically insignificant (Brześć Kujawski, Sopot, Iwonicz, Rymanów, Krynica, Szczawnica, Muszyna, Rabka, Augustów, Busko, Gołdap, Solec). Noteworthy, in the case of a small number of observations it is more difficult to confirm the statistical significance of the correlation coefficient, and to achive this it is needed to identify a high-power correlation.

2. Within the group of communes for which the relationships are statistically significant, spa specialization is usually positively correlated to SSD, SSD significantly influence on spa specialization, SSD is rising, Spa specialization is rising, nights spent number is rising.

3. Four different development patterns of spa communes were identified and evaluated:

- the rise of nights spent connected with the growth of spa specialization and the rise of SSD (Ciechocinek, Solina, Uście Gorlickie, Ustroń, Nałęczów) - a risky combination of trends due to growing dependence on state distribution channel, 
- the drop of nights spent connected with the rise of spa specialization and the growth of SSD (Ustka) double negative combination of trends, due to overlap in the fall of night stays and growing dependence on state distribution channel,

- the rise of nights spent connected with the fall of spa specialization and the drop of SSD (Kraków i Goczałkowice) - a positive combination of trends due to growing destination revenues in the segment of valuable customers, such as tourists sleeping outside the spa establishments and commercial spa patients,

- the rise of nights spent connected with the growth of spa specialization and the decrease of SSD (Horyniec i Inowrocław) - a positive combination of trends due to base the growth of destination revenues on valuable clients, as in this case commercial spa patients.

To sum all, using number of nights spent variable, because of its correlation with destination revenues from visitors service it's worth to evaluate identified spa destinations development patterns, conditioning existence of link between number of nights spent and analysed indicators. Verification of this assumption deserves further research.

The limitations of this study are as follows. Firstly, it focuses on the case of one single country from Central Europe. Secondly, 22 Polish spa communes have been analysed, representing about half of the population of spa communes in Poland. Thirdly, secondary data analysis was limited to period from 2005 to 2015. Fourthly, SSD indicator concerns only spa inpatients, omitting outpatients. These four facts together limits the spatial, temporal and objective possibility of the findings generalization.

\section{References}

Central Statistical Office of Poland Local Data Bank. Retrieved from: https://bdl.stat.gov.pl (31.08.2017).

Derco, J., Pavlisinova, D. (2016). Financial position of medical spas - the case of Slovakia. Tourism Economics, 4 (23), $867-873$.

Dryglas, D., Różycki, P. (2016). European spa resorts in the perception of non-commercial and commercial patients and tourists: the case study of Poland. E-review of Tourism Research (eRTR), 1/2 (13), 382-400.

Dryglas, D., Różycki, P. (2017). Profile of tourists visiting European spa resorts: a case study of Poland. Journal of Policy Research in Tourism, Leisure and Events, 3 (9), 298-317.

Dryglas, D., Salamaga, M. (2017). Applying destination attribute segmentation to health tourists: A case study of Polish spa resorts. Journal of Travel and Tourism Marketing, 4 (34), 503-514.

Kozarkiewicz, A., Kabalska, A. (2017). Kuracjusz i klient: ewolucja propozycji wartości w modelach biznesowych przedsiębiorstw uzdrowiskowych w Polsce. Marketing i Rynek, 10 (CD), 296-309.

Mankiw, N.G., Taylor, M.P. (2016). Makroekonomia. Warszawa: PWE.

Romanova, G.M., Vetitnev, A., Dimanche, F. (2015). Health and wellness tourism. In: F. Dimanche, L. Andrades (eds.), Tourism in Russia: A Management Handbook (pp. 231-287). Bingley: Emerald.

Stelmach, P. (2017a). Struktura dystrybucji usług uzdrowiskowych a funkcja uzdrowiskowa gmin. Koncepcja i wstępne wyniki badań. Prace Naukowe Uniwersytetu Ekonomicznego we Wrocławiu, 473, 552-561.

Stelmach, P. (2017b). Trendy dystrybucji usług uzdrowiskowych w gminach województwa podkarpackiego. In: B. Gierczak-Korzeniowska, P. Żegleń (eds.), Turystyka a rozwój regionalny - szanse, wyzwania, perspektywy. Rzeszów: Uniwersytet Rzeszowski, in press.

Stelmach, P. (2017c). Spa Services Distribution And Specialization In Kujawsko-Pomorskie, Pomorskie And Podkarpackie Voivodeships Communes. Turyzm, 1 (27), 63-70.

Stelmach, P. (2017d). Struktura dystrybucji usług uzdrowiskowych a funkcja uzdrowiskowa gmin małopolskich. Studia Oeconomica Posnaniensa, in review. 
Stelmach, P. (2017e). Struktura dystrybucji usług uzdrowiskowych a funkcja uzdrowiskowa gmin śląskich. Prace Geograficzne, in review. Szromek, A.R., Romaniuk, P., Hadzik, A. (2016). The privatization of spa companies in Poland - An evaluation of policy assumptions and implementation. Health Policy, 120, 362-368.

Vrkljan, S., Hendija, Z. (2016). Business performance of health tourism service providers in the Republic of Croatia. Acta Clinica Croatica, 1 (55), 79-85.

Cite this anticle aS: Stelmach, P. (2018). Spa services distribution and spa specialization in Eastern Poland spa communes. European Journal of Service Management, 2 (26), 233-241. DOI: 10.18276/ejsm.2018.26-29. 